\title{
Protective gloves on manual sugar cane cutting are really effective?
}

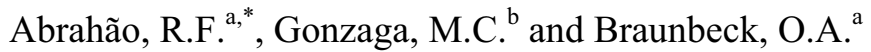 \\ ${ }^{a}$ Faculty of Agriculture Engineering, Campinas State University, 501 Candido Rondon ave, 13083-875, \\ Campinas, SP, Brazil \\ ${ }^{\mathrm{b}}$ Fundacentro, Ministry of Labor and Employment, 710 Capote Valente st., São Paulo, SP, Brazil
}

\begin{abstract}
Problems related to the use of personal protective equipment (PPE), specially the use of protective gloves for the manual sugar cane cutting, motivated this research, made possible by a tripartite negotiation involving the Ministry of Labor, the Union of Rural Workers and the Employer's Association of sugarcane agribusiness. The main objective was to evaluate, from an ergonomics perspective, the impact of use of the gloves during the manual cane sugar cutting, raising questions on safety, effectiveness and comfort. The research was carried in a sugarcane industry of São Paulo for two seasons involving 47 workers who made a qualitative analysis of acceptance of four models of protective gloves. The methodology included the use of semi-structured interviews, questionnaires and field observations and the experimental determination of the coefficient of static friction developed between the gloves and the surfaces of the machete handle. The main results indicate the general inadequacy of the gloves currently used forcing the employees to improvise. Workers found the glove of leather and nylon scraping the best reported for comfort in use. The overall results highlight the problem of detachment of test standards for the manufacture of PPE, ignoring users and the activity to be performed.
\end{abstract}

Keywords: PPE, protective gloves, coefficient of friction, manual cutting, sugar cane

\section{Introduction}

Problems related to the use of personal protective equipment (PPE) for the manual sugar cane cutting generated a comprehensive research, made possible by a tripartite negotiation involving the Ministry of Labour and Employment, the Union of Rural Workers and the Employer's Association of sugarcane agribusiness sector. This work is a partial result of that research, specifically involving the use of protective gloves. Their use in the sugar cane manual cutting activity is very important, since the hand is the body part which is most affected in that kind of activity and the machete is the main causative agent of accidents $[2,4,5]$.

Cutting is divided into the following operations: the base cut of the culms, the tip cut and the ordered deposition of the culms. Armed with machetes, the workers must cut the cane with one or more blows at the base and to carry them with their arms up to a pre-determined place to a ordered deposition the culms, so that later in the production process, loading tractors will transport them to the production plant. Figure 1 shows a female worker doing the tip cut.

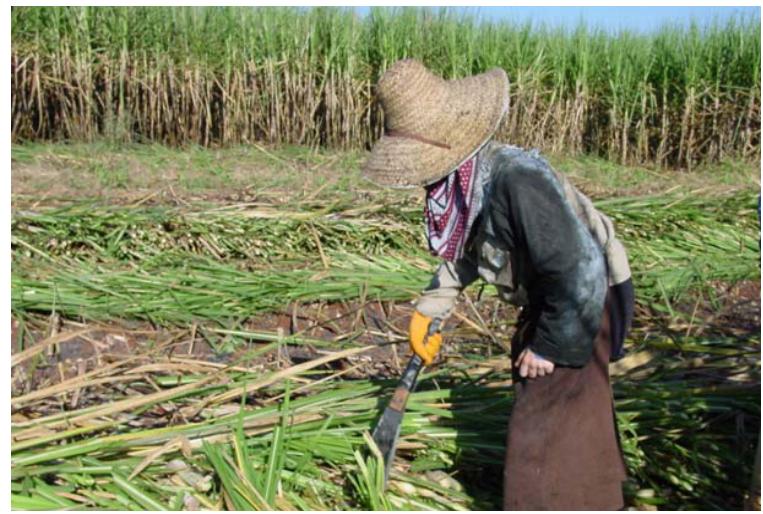

Fig 1. Worker doing sugar cane tip cut.

${ }^{*}$ Corresponding author. E-mail: roberto@feagri.unicamp.br 
Previous researches addressed the interaction between gloves and hand tools, emphasizing the relationship between the coefficient of friction of the interface and the requirement of grip strength [7], the interference of tactile feedback [1] and, in the case of manual sugar cane cutting, the emergence of hand injuries caused by hand tool use and the feeling of discomfort and insecurity that workers experience due to the lack of adherence of the glove with the machete handle [6]. This lack of adherence also constitutes a risk factor for musculoskeletal disorders, as it requires an increasing grip strength due to the reduction of tactile sensitivity [3]. The use of protective gloves also cause injury because the cane is burned to facilitate the manual cutting producing ashes, that, with the sucrose and water, form a mixture which in contact with the gloves scrapes, penetrate the hands skin producing fissures and dermatitis [8].

This study sought to evaluate, from an ergonomics perspective, the impact of the protective glove use during the performance of manual sugar cane cutting, considering the performed activity and raising questions on safety, effectiveness and comfort. It was tried to identify the determinants of activity that can cause accidents and diseases as well as the strategies developed by workers to minimize the constraints and to meet the standards imposed by the work organization. As specific goals, this work determined the coefficient of static friction, through experimental tests, for four types of protective gloves and wood employed in machete handles. It also carried a qualitative analysis of acceptance of four models of protective gloves used by the workers.

\section{Methods}

This research was carried in a sugarcane industry in São Paulo, Brazil, for two seasons, involving 82 workers, who made a qualitative analysis of acceptance of four models of protective gloves (leather and metal scrapings, Kevlar, cotton and rubber and zest leather and nylon). The methodology included the use of semi-structured interviews, questionnaires and field observations.

It was formulated the hypothesis that the coefficient of static friction developed between the gloves and the surfaces of the machete handle, a factor directly linked to the demands of grip strength, depends on the glove type, glove condition (new or used) and surface type (bare wood or rubber wood). To test this hypothesis, it was determined the coefficient of static friction, through experimental tests, for four types of protective gloves and wood employed in machete handles. It was sought to evaluate the influence of the independent variables type and condition of gloves use and type of timber flooring machete handle in the dependent variable coefficient of friction. Figure 2 shows the specimens, the handle of the knife and gloves used in the research, while Figure 3 shows the experimental set up to measure the coefficient of friction.

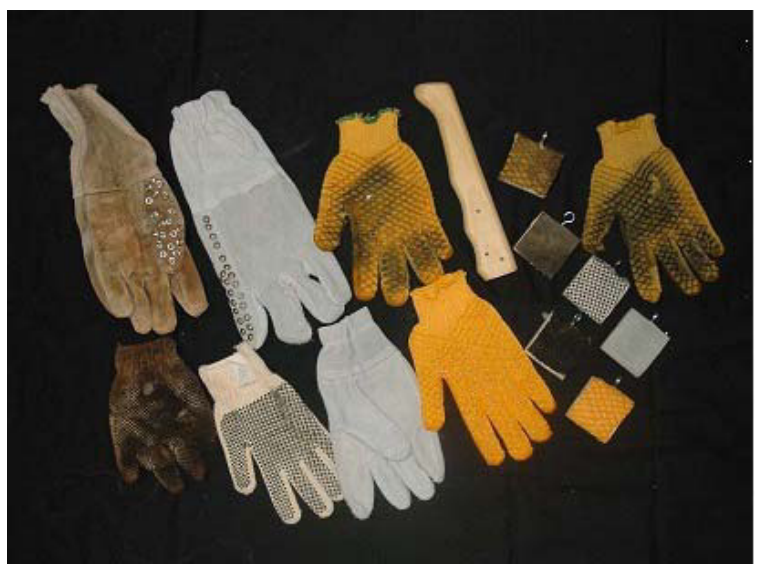

Fig. 2. Gloves, machete handle and specimens used for the determination of the coefficient of static friction.

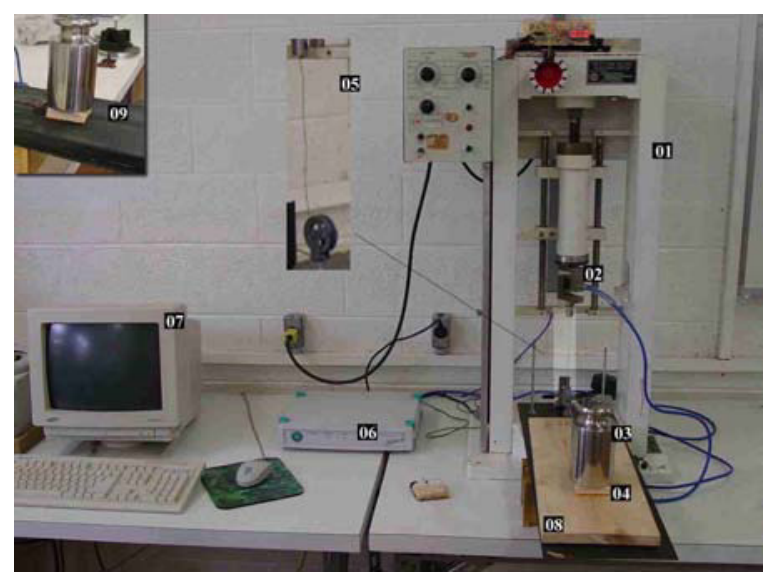

Fig. 3. Experimental set up for the determination of the coefficient of static friction.

For the analysis of subjective and objective data it were used the softwares EPI INFO and SAS. The applied statistical model was the analysis of variance (ANOVA) at 5\% significance level. 


\section{Results and Discussion}

The main results indicate that the machete handle has low adherence to the protective glove made of leather scrapes, the usual glove used by the workers which causes workers to improvise, like booting the cable. The seams of the protective glove match the grip of the machete handle, which injured the users hands; glove hardens in contact with sucrose and ash present in sugarcane, making it difficult to handle the machete and reducing the tactile feedback. It was also shown the anthropometric inadequacy of zest leather gloves commonly provided because they are of single size, given the dimensional variability of the hands of users (Figure 4).

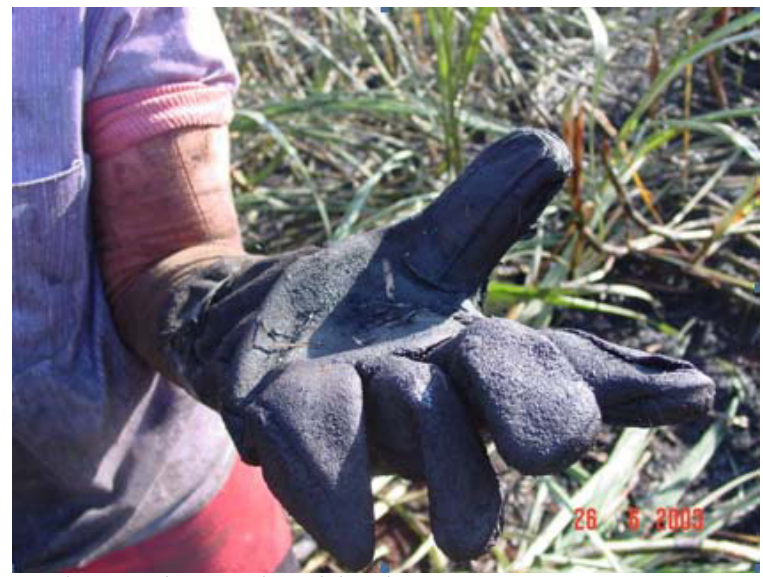

Fig.4. Inadequate size of the gloves.

It was proved that the operational strategy developed by workers (booting the machete handle) was successful, because it was found statistical difference between the average values of the coefficient of static friction. Figure 5 shows the strategies adopted by the workers to minimize the lack of grip and the inadequate handle size.

In the study of acceptance of different glove models, the average coefficient of friction was not decisive in choosing the best glove for the work performed, since booting the handle proved to be a good decision. Workers found the glove of leather and nylon scraping the best reported for comfort in use, because the leather is soft and inseams do not hurt the hands. Table 1 shows the overall results for the acceptance of the different gloves.

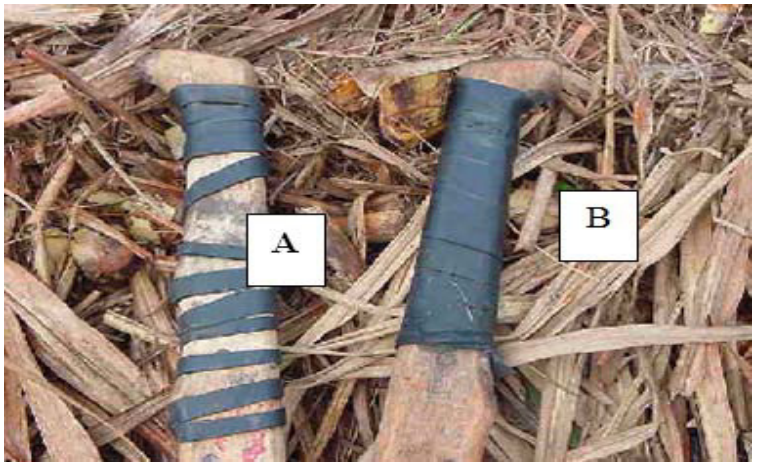

Fig. 5. Booting the handle to deal with the lack of grip and the inadequate size.

Table 1

Qualitative assessment of the different protective gloves (\% positive answers)

\begin{tabular}{|l|l|l|l|l|}
\hline $\begin{array}{l}\text { Qualitative } \\
\text { assessment }\end{array}$ & $\begin{array}{l}\text { Cotton and } \\
\text { vubber }\end{array}$ & Kevlar & $\begin{array}{l}\text { Leather and } \\
\text { metal scrapings }\end{array}$ & $\begin{array}{l}\text { leather } \\
\text { and nylon }\end{array}$ \\
\hline Good size & 100 & 34,2 & 6,5 & 93,9 \\
\hline $\begin{array}{l}\text { Do not squeeze the } \\
\text { hands }\end{array}$ & 97,2 & 89,5 & 21,7 & 100 \\
\hline $\begin{array}{l}\text { It is not large } \\
\begin{array}{l}\text { Do not affect the } \\
\text { movements }\end{array}\end{array}$ & 86,1 & 86,8 & 6,5 & 90,9 \\
\hline $\begin{array}{l}\text { Does not slip in the } \\
\text { hand of the machete }\end{array}$ & 69,4 & 66,6 & 17,4 & 78,8 \\
\hline $\begin{array}{l}\text { Does not hurt the } \\
\text { hands }\end{array}$ & 77,8 & 89,5 & 2,2 & 15,2 \\
\hline Does not harden & 97,2 & 60,5 & 19,6 & 78,8 \\
\hline $\begin{array}{l}\text { Does not cause } \\
\text { itching }\end{array}$ & 100 & 100 & 2,2 & 36,4 \\
\hline The glove tears & 83,3 & 97,4 & 69,6 & 90,9 \\
\hline \begin{tabular}{l} 
It's a good glove \\
\hline
\end{tabular} & 75,0 & 63,2 & 97,8 & 81,8 \\
\hline
\end{tabular}

Table 2 shows the experimental results of the measurement of the coefficient of static friction for the different types of gloves, the state of the gloves (new or used) and the condition of the machete handle (without or with rubber). It was found statistical difference $(p<0.05)$ between the mean values of the average coefficient of friction for gloves types, glove condition (new or used) and handle condition. 
Table 2

Average coefficient of static friction for the interactions between type of glove, state (new or used) and condition of the machete handle.

\begin{tabular}{|c|c|c|c|c|c|}
\hline \multirow{2}{*}{\multicolumn{2}{|c|}{ Glove }} & \multicolumn{2}{|c|}{ Handle without rubber } & \multicolumn{2}{|c|}{ Handle with rubber } \\
\hline & & Mean & $\begin{array}{l}\text { Standard } \\
\text { deviation }\end{array}$ & Mean & $\begin{array}{l}\text { Standard } \\
\text { deviation }\end{array}$ \\
\hline \multirow{4}{*}{$\begin{array}{l}\mathrm{N} \\
\mathrm{E} \\
\mathrm{W}\end{array}$} & Cotton / rubber & 1,13 & 0,04 & 1,44 & 0,14 \\
\hline & Kevlar & 1,28 & 0,07 & 1,45 & 0,18 \\
\hline & $\begin{array}{l}\text { Leather / metal } \\
\text { scrapping }\end{array}$ & 0,68 & 0,04 & 1,22 & 0,10 \\
\hline & Leather / nylon & 0,69 & 0,03 & 1,26 & 0,05 \\
\hline \multirow{4}{*}{$\begin{array}{l}\text { E } \\
D\end{array}$} & Cotton/ rubber & 1,02 & 0,12 & 1,40 & 0,04 \\
\hline & Kerlar & 1,04 & 0,06 & 1,31 & 0,05 \\
\hline & $\begin{array}{l}\text { Leather / metal } \\
\text { scrapping }\end{array}$ & 0,47 & 0,05 & 1,32 & 0,04 \\
\hline & Leather / nylon & 0,48 & 0,02 & 1,48 & 0,06 \\
\hline
\end{tabular}

\section{Conclusions}

The overall results of the research, when confronted with the gloves certification process, highlight the problem of detachment of test standards for the manufacture of PPE, ignoring users and the activity to be performed.

\section{References}

[1] A. Muralidhar, R.R. Bishu and M.S. Haldeck. The development and evaluation of an ergonomic glove. Applied Ergonomics. London, v. 30, p. 555-563, 1999.

[2] A. S. V. Bomfim, F. A. B Xavier, M. R. Sampaio, R. Piva Canas e bagaços: a organização do trabalho e as repercussões no quadro de saúde e segurança do cortador de cana do Recôncavo Baiano. 54 p. Fundacentro - Salvador, 2001.

[3] H. Kinoshita. Effect of gloves on prehensile forces during lifting and holding tasks. Ergonomics, London, v. 42, $\mathrm{n}^{\mathrm{o}} 10$, p. 1372-1385, 1999.

[4] I. Reina, M. L. Gondim and A. M. Ludemir. Os trabalhadores invisíveis: condição de vida e trabalho das crianças e adolescentes. Relatório de Pesquisa. Recife. Centro Josué de Castro de Estudos e Pesquisas, 1993, 58 p.

[5] M. C. Gonzaga, M. A. Bussacos, M. A Silva and L. Ferreira. Estudo das comunicações de acidentes de trabalho na região de Catanduva. São Paulo: Fundacentro, 1996. 58 p.

[6] M. C. Gonzaga. O uso dos equipamentos individuais de proteção e das ferramentas de trabalho no corte manual da cana-de-açúcar. 39 p. São Paulo, Fundacentro, 2002.

[7] N. Tsaousidis and A. Freivalds. Effects of gloves on maximum force and the rate of force development in wrist flexion and grip. Twenty-First Annual American Society of Biomechanics. Califórnia: Clemson University. p. 24-27, 1997.

[8] S. A. Ali. Atlas de dermatoses ocupacionais. Ministério do Trabalho e Emprego, FUNDACENTRO, 2001. CD-ROM. 